\title{
Ovarian Dermoid Cyst with Squamous Cell
} Carcinoma

National Cancer Institute

\section{Source}

National Cancer Institute. Ovarian Dermoid Cyst with Squamous Cell Carcinoma. NCI

Thesaurus. Code C39998.

A secondary squamous cell carcinoma that has developed in an ovarian dermoid cyst. 